The report of St Michael's College was presented by its Principal, the Reverend Dr John Holdsworth, who was able to report an encouraging year for the College.

Another report presented was an interim report on a proposal to establish an ecumenical Bishop in Wales. The purpose of this office would be lead existing ecumenical work, to assist with the development of new ecumenical work and further to promote the cause of Christian unity. It is a concept not without its difficulties but which has been the subject of much consideration by Enfys, the Commission of the Covenanted Churches in Wales, and a report on progress was given by the Reverend Marion Dowsett and Mr Gethin Jones.

The Anglican Consultative Council had met in September 1999 at the same time as the last meeting of the Governing Body, thus leading to the absence from that meeting of the Archdeacon of Wrexham, the Venerable Brian Williams, and Miss Sylvia Scarf, who accordingly presented a report on the proceedings at this meeting. ACC meetings undertake a heavy agenda and it was clear from the report that this last meeting had been no exception.

Two important measures received final approval, the first of these being a bill to implement the Reuilly Agreement which seeks to promote co-operation between the Church in Wales and the Church of the Augsburg Confession of Alsace and Lorraine, the Evangelical Lutheran Church of France, the Reformed Church of Alsace and Lorraine, the Reformed Church of France, the Church of England, the Church of Ireland and the Scottish Episcopal Church. This was the first bill to be promoted under the new bill procedure which was referred to in the report of the Governing Body's meeting in September 1999, which dispensed with the formal first reading and allowed for subsequent stages to be taken together, subject to certain safeguards to ensure that a potentially controversial bill is debated fully. This bill, deemed non-controversial by the Select Committee set up under the new arrangements to scrutinise it, was not challenged when presented to the Governing Body and was therefore passed and promulgated as a new canon at the same meeting.

In addition to passing the bill, the Governing Body considered and approved a proposal by the Bench of Bishops to authorise the continued use of a number of alternative orders of service on the basis of the Bench's indication that by the end of 2006 the full revision of all the orders concerned would have been completed, and that accordingly it would be possible to put forward definitive proposals by that time.

\title{
THE GENERAL SYNOD OF THE CHURCH OF ENGLAND
}

\author{
BRIAN HANSON \\ Registrar and Legal Services Director
}

At the February 2000 Group of Sessions of the General Synod two Amending Canons were promulged, namely No 22, which gives power to the bishop to permit a parish for a limited period to use forms of service which are no longer approved for use in the Church (see 5 Ecc LJ 209), and No 23, which permits authorised services to be used in languages other than English and in British Sign Language for the deaf (see 5 Ecc LJ 210).

Final approval was given to Amending Canon No 25, which gives ex officio membership of the Upper House of Convocation (and thereby to the General Synod House of Bishops) to the Bishop of Dover. It is expected that the Canon will be promulged at the July Sessions in time to take effect before the elections to Convocation. 
The Synod commenced the revision stage of the draft Clergy Discipline Measure (formerly entitled the Ecclesiastical Jurisdiction (Discipline) Measure) (see 5 Ecc LJ 382) but, because of the volume of liturgical business, debate was adjourned at clause 7. It is hoped that the revision stage will be completed at the July Group of Sessions. The main changes to the Measure made by the Revision Committee include inserting as a clause of the Measure matters relating to the standard of proof, to the requirement for a public hearing and to the decision of the tribunal. On the question of the composition of the tribunal, it was concluded that it should be made up of three members. The Committee was conscious that having more members would increase the costs and make it more difficult to agree dates; the strength of secular precedents (such as magistrates' courts and industrial tribunals) were also noted. The Committee also decided that cases before the tribunal should be decided by majority rather than that the members should be unanimous: this was considered to be appropriate given the fact that the Measure was establishing a disciplinary procedure, not a criminal one.

The Revision Committee for the draft Synodical Government (Amendment) Measure (see 5 Ecc LJ 383) had also completed its work and had tabled its report for revision in full Synod. However, as with the Clergy Discipline Measure, there was insufficient time to debate it, and the revision stage had to be held over until the July Group of Sessions, a report of which will appear in the next issue of this Journal.

The July Sessions are the last of the quinquennium. Fresh elections to the Convocations and to the House of Laity will be held in the period between July and October, and the new Synod will be inaugurated by the Queen on 14th November in Westminster Abbey.

\title{
THE GENERAL SYNOD OF THE SCOTTISH EPISCOPAL CHURCH
}

\author{
IVOR GUILD \\ Writer to the Signet
}

Out of the usual menu of canons and financial measures at the Synod in 2000 the most popular choices were the Canon of the Election of Bishops, a paper (massive and meaty) by the Clergy Personnel Commission and, for emotional content, the possibility of female bishops. This last was quickly disposed of by the appointment of a committee to produce a Green Paper for next year's Synod, though not before those who oppose female priests had argued for delay (possibly to the next millennium) on the ground that matters were proceeding too fast.

The Canon of Election of Bishops (Canon 4) came up for second reading. No canon has been the subject of more amendments in the past, but the version now proposed seeks to inject into the procedure a provincial element on the ground that the appointment of a bishop creates ripples far beyond his own diocese. Dioceses, however, are jealous of their perceived right to select the person who will hold sway over them, and in this new canon the last word remains in local hands.

On a vacancy occurring a Preparatory Committee will be set up under the convenership of the Primus, consisting of five members of the Provincial Panel (a new body made up of one lay person and one cleric from each diocese), a bishop, and two further lay and clerical members chosen by the diocesan synod of the diocese which is vacant. With the aid of a Description of the Diocese compiled by the Diocesan Synod (which is to contain the relevant future plans and intentions for the work of 